\title{
Effect of forage conservation (hay or silage) on chemical composition of milk
}

\author{
JB Coulon ${ }^{1 *}$, P Pradel $^{2}$, I Verdier ${ }^{3}$ \\ 'Laboratoire adaptation des herbivores aux milieux, Inra, Theix, 63122 Saint-Genès-Champanelle; \\ 2 Inra, domaine expérimental de la Borie, 15190 Marcenat; \\ ${ }_{3}^{3}$ Laboratoire de recherches fromagères, Inra, 36, rue de Salers, 15000 Aurillac, France
}

(Received 13 February 1996; accepted 12 June 1996)

\begin{abstract}
Summary - Forty-two lactating multiparous cows were used in a changeover design with two periods of 4 weeks. During each period cows were offered an isocaloric diet composed either of grass silage ( $12 \mathrm{~kg}$ dry matter/day) or hay ( $12.5 \mathrm{~kg}$ dry matter/day). Hay and grass silage were harvested the same day ( 7 June) in the same field of native mountain grassland. Each diet was supplemented with the same quantity of a mixture of barley and soya bean meal in proportions calculated to keep the overall rations isonitrogenous. The cows fed grass silage yielded $0.7 \mathrm{~kg} / \mathrm{day}(P<0.05)$ more milk than those fed hay, but their milk was significantly poorer in fat $(-1.2 \mathrm{~g} / \mathrm{kg})$, proteins $(-1.0 \mathrm{~g} / \mathrm{kg})$ and caseins. As energy balance and live weight changes were similar with the two diets, these results are linked only to a dilution effect of milk solids secreted. The casein/protein ratio and the soluble protein concentration of the milk were not significantly different between the two types of forage. The calcium concentration was lower, and the phosphorus concentration higher when cows were fed hay.
\end{abstract}

dairy cows / milk composition / grass silage / hay

Résumé - Effet du mode de conservation de l'herbe (foin ou ensilage) sur la composition chimique du lait. Quarante-deux vaches laitières multipares en milieu de lactation ont été utilisées dans un essai en inversion. Pendant chacune des deux périodes de 4 semaines, les animaux ont reçu une ration de fourrage isoénergétique, à base d'ensilage d'herbe ( $12 \mathrm{~kg}$ de matière sèche/jour) ou de foin (12,5 kg de matière sèche/jour). Ces deux fourrages avaient été récoltés le même jour sur la même

* Correspondance et tirés à part.

Fax: (33) 04736241 18; e-mail: jbe@clermont.inra.fr 
parcelle de prairie naturelle. Chaque ration a été complémentée avec la même quantité d'un mélange d'orge et de tourteau de soja dont les proportions ont été calculées de manière à ce que les apports azotés soient voisins et non limitants dans les deux traitements. Les vaches recevant de l'ensilage d'herbe ont produit $0,7 \mathrm{~kg} / \mathrm{jour}(p<0,05)$ de lait de plus que celles recevant du foin, mais leur lait a été significativement plus pauvre en matières grasses $(-1,2 \mathrm{~g} / \mathrm{kg})$, en protéines $(-1,0 \mathrm{~g} / \mathrm{kg})$ et en caséines. Les bilans énergétiques et les variations de poids vif ayant été voisins dans les deux lots, ces résultats sont essentiellement dus à un effet de dilution des matières utiles secrétées. Le rapport caséines/protéines et la teneur en protéines solubles du lait n'ont pas été significativement différents selon le type de ration de base. La teneur en calcium du lait a été significativement plus faible, et celle en phosphore plus élevée, avec la ration à base de foin.

\section{vache laitière / composition du lait / ensilage d'herbe / foin}

\section{INTRODUCTION}

Among the numerous studies on the influence of feeding on fat and protein concentration of milk, some have demonstrated that grass silage based diets could lead to lower protein concentration in milk than hay based diets (Bertilsson and Burstedt, 1983; Coulon et al, 1985). However, in most studies, energy supply, which is an important factor influencing milk protein concentration, was different among the diets, and could have modified the effect. In the experiments where nutritive supplies were identical (Coulon and Garel, 1993; Coulon et al, 1995), the decrease in protein and fat concentration was accompanied by an increase in milk production, so that milk solids production was the same between the two diets. Unfortunately, in these two trials, the type of flora (ryegrass or cooksfoot) that can have an effect on milk yield and composition (Demarquilly, 1963; Thompson et al, 1985), and the stage of harvest (first or second cut), were different between grass silage and hay.

The aim of this study was to describe and analyse the milk production and chemical composition of milk in cows fed a diet based on hay or silage (issued from the same field and harvested the same day) and rationed to provide identical predicted levels of energy and protein supplies (according to INRA recommendations [1989]).

\section{MATERIALS AND METHODS}

\section{Animals and feeding}

Forty-two multiparous Holstein (HO, $n=14$ ), Montbéliarde (MO, $n=14$ ) and Tarentaise (TA, $n=14$ ) cows were used in a changeover design with two periods of 4 weeks. These animals had calved between 9 November and 1 January. In early lactation, all cows were fed a diet of grass silage from native mountain grassland (ad libitum) and cocksfoot second-cut hay (4 kg/day), supplemented according to INRA recommendations (1989). Three weeks prior to the beginning of the experiment, all animals were fed a diet composed of hay $(5 \mathrm{~kg}$ dry matter [DM]/day) and grass silage (7 kg DM/day). Hay (H) and grass silage (GS) were harvested the same day ( 7 June) in the same plot of native mountain grassland, composed of meadow grass (28\%), perennial ryegrass (22\%), cocksfoot (15\%) and other species (mainly white clover, dandelion and bromegrass). Silage was ensiled unwilted using a drum harvester and with preservative $(70 \%$ formic acid, $30 \%$ formalin) applied at a rate of $3 \mathrm{l} / \mathrm{t}$ fresh matter. Hay remained $36 \mathrm{~h}$ on the field until DM content reached at least $55 \%$. It was then barn-dried. The characteristics of the different feeds are specified in table I. The trial began on 20 February. Two groups of seven cows per breed were formed on the basis of production performances during 
the 3 pre-experimental weeks. Two experimental periods, each of 4 weeks, were then conducted, during which each group was successively fed the two types of forage. Throughout each period, the quantities of each forage provided were calculated so that energy supplies were identical. They were, respectively, 12.5 and $12 \mathrm{~kg} \mathrm{DM} /$ day for groups H and GS. The two diets were supplemented with $3 \mathrm{~kg} /$ day of a commercial concentrate ( $20 \%$ wheat, $20 \%$ barley, $7 \%$ soya bean meal, $15 \%$ rapeseed meal, $30 \%$ beet pulp, $5 \%$ beet molasses), and a mixture of soya bean meal and barley. The quantites of concentrate given were determined for the whole experiment, so as to cover the maintenance and milk production requirements monitored over the pre-experimental period, according to INRA recommendations (1989). These quantites remained unchanged for any given animal throughout the experiment, and from one group to the other. The respective proportion of barley and soyabean meal in the concentrate differed according to the type of forage, so that the nitrogen supplies were as close as

Table I. Composition and nutritive value of forages.

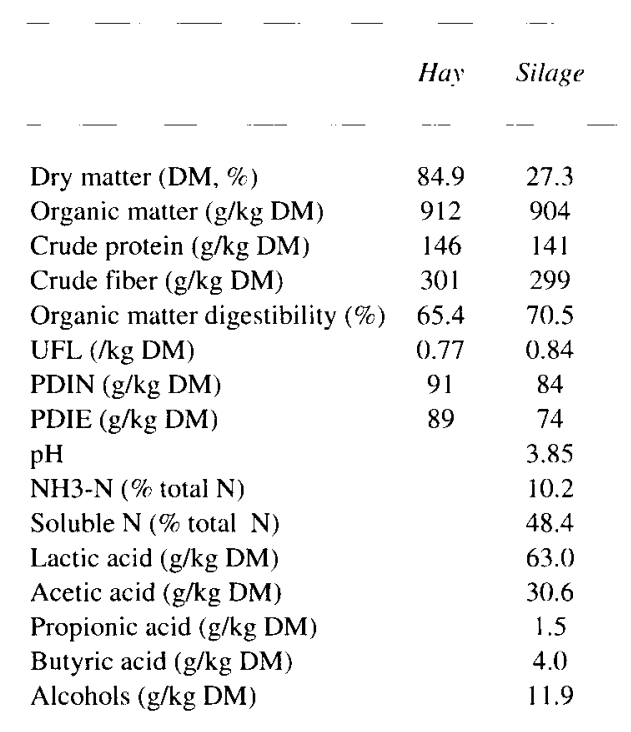

possible and non-restrictive. On average, starch supply was 2.4 and $1.9 \mathrm{~kg}$ /day in groups $\mathrm{H}$ and GS, respectively (ie, 14 and $11 \%$ of the total DM intake). Transition from one diet to the other was carried out over 3 days. At the end of the second experimental period, all animals were again fed the pre-experimental mixed diet for a 2 week period. Throughout the entire experiment, the cows were given $100 \mathrm{~g} /$ day of a mineral additive $(6 \mathrm{P}, 22 \mathrm{Ca})$.

\section{Samples and measurements}

The quantity of milk produced was individually weighed after each milking and the fat and protein concentrations were determined 5 days a week, at each milking. Concentrate and forage intakes were measured individually every day. The DM content of the forages was measured 5 days a week. The DM content of silage was corrected to allow for DM losses during ovendrying according to Dulphy and Demarquilly (1981). The chemical composition of the forages was determined three times during the trial, as were the digestibilities of dry and organic matter, by using groups of four wether sheep per forage type during measurement periods of 1 week after a 2 week adaptation period. These data enabled the calculation of the nutritive value of the forages, according to INRA recommendations (table I). The cows were weighed once a week, on the Tuesday, at the beginning of the afternoon.

During the last 2 weeks of each period, individual milk samples were taken once a week at the morning milking for the analysis of total proteins, soluble proteins, caseins (Rowland, 1938), urea, phosphorus and calcium concentrations.

Energy and nitrogen balance were calculated from the difference between food input and the animals' requirements, according to INRA recommendations (1989). The energy content of the milk produced was calculated from its fat and protein concentrations according to the formula proposed by Sjaunja (1989). 
Table II. Food intake, milk production and live weight change data (means of the 2 last weeks of each period).

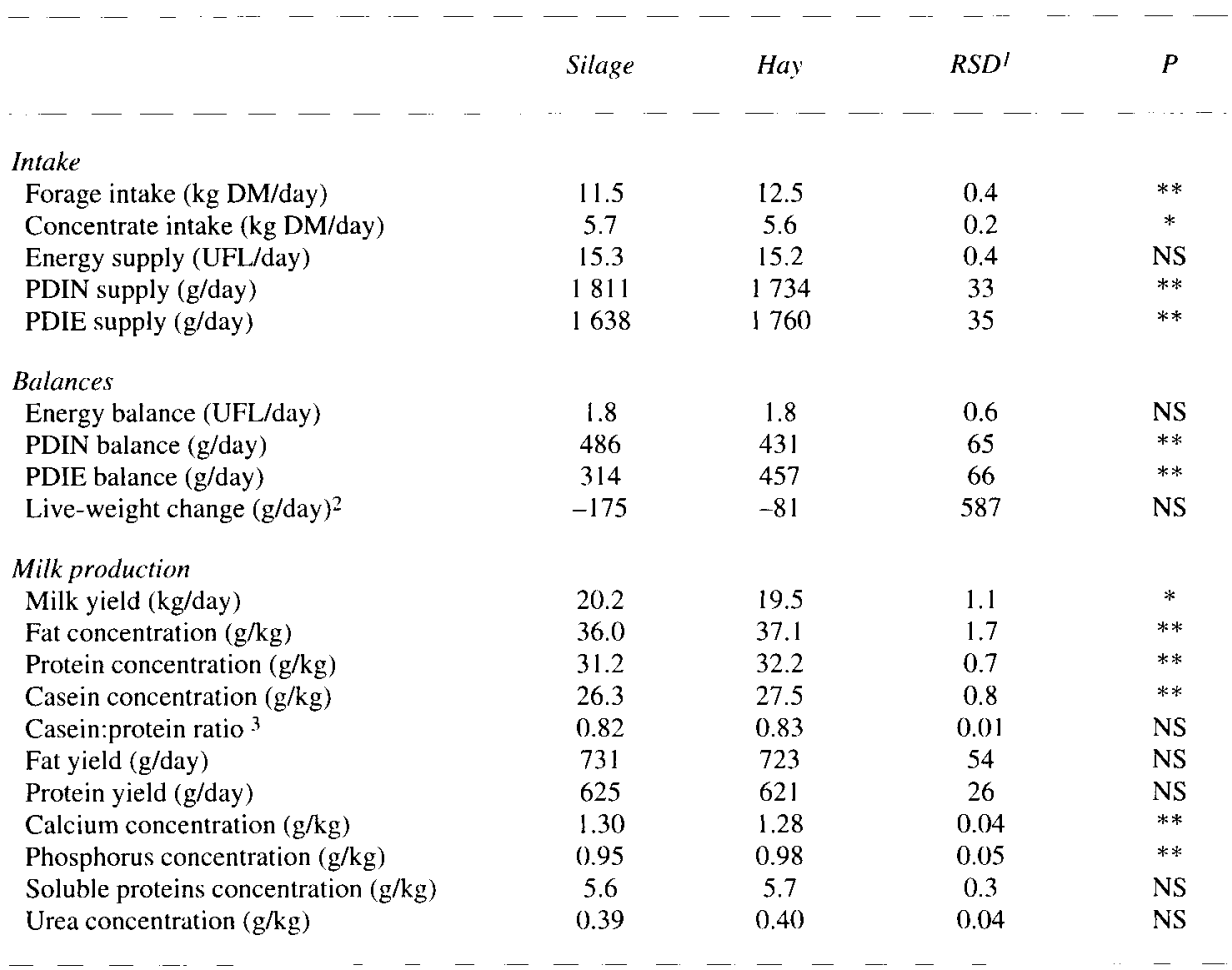

${ }^{1}$ Residual standard deviation; ${ }^{2}$ calculated between the $\mathrm{Ist}$ and the 4 th week of each period; ${ }^{3}$ this ratio was computed by using the protein content of the two morning milk samples used for casein content determination $(32.0$ and $33.2 \mathrm{~g} / \mathrm{kg}$ in group GS and $\mathbf{H}$, respectively). This protein content was slightly different from that computed on the samples collected during the two last week of each period, which figures in the table. NS : not significant.

\section{Analysis of results}

The analysis of results was carried out using the mean data of the last 2 weeks of each experimental period. These data were processed by analysis of variance (SAS, 1987). Fixed effects included in the model were the type of forage, breed, animal (nested within breed) and period, as well as breed $x$ treatment interaction. In the absence of significant breed $x$ treatment interaction, only results concerning the type of forage are presented.

\section{RESULTS}

As planned, the energy supply was identical in the two groups (table II). In the GS group, the PDIN supply was slightly higher and the PDIE supply slightly lower than in the $\mathrm{H}$ group. Throughout the trial, the animals showed positive energy and nitrogen balances. The passage from one type of diet to another was not accompanied by marked refusals of feed.

Cows fed grass silage yielded $0.7 \mathrm{~kg} /$ day $(P<$ 0.05 ) more milk than those fed hay. Their milk 


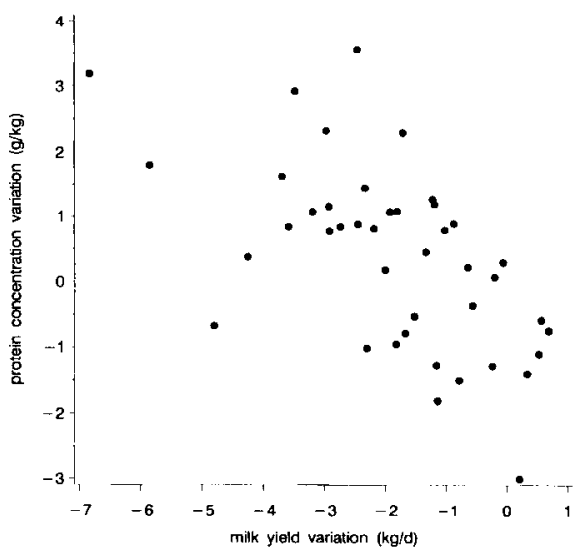

Fig 1. Relationship between milk yield and protein concentration individual variations between the two experimental periods.

was significantly poorer in fat, proteins and caseins $(P<0.01)$ than those belonging to group $H$. For a given cow, variations in protein concentration from one period to the next were inversely linked to those of milk yield (fig 1 ). The proportion of caseins in the proteins was identical for the two rations $(83 \%)$ ). Overall, the yield of milk solids was identical for group $\mathrm{H}$ and GS (table II). The calcium concentration of the milk was lower $(P<0.01)$ and the phosphorus concentration higher $(P<0.01)$ in $\mathrm{H}$ group, but the differences, although significant, were very small. The urea concentration of the milk was high, in relation with the positive PDIN balance, and similar in the two groups, as was soluble protein concentration. Live weight changes were low and similar in the two groups.

\section{DISCUSSION}

This trial confirmed the beneficial effect of grass silage-based diets on milk production to the detriment of milk solids concentration, as already reported relative to hay (Journet and Dulphy, 1973; Burstedt and Lingvall, 1977; Coulon et al, 1995) or maize silage (Vérité and Journet, 1971).

The differences observed were relatively moderate (below $1 \mathrm{~kg}$ milk and around $1 \mathrm{~g} / \mathrm{kg}$ for each content) and smaller than those obtained in our previous trials (Coulon and Garel, 1993; Coulon et al, 1995), perhaps because in the latter, hay and silage floral types were different and could have had a specific effect on animal performances (Thomas, 1984a).

The differences in performances between hay- and silage-based diets rationed to provide the same amount of energy and protein are generally ascribed to a different distribution of energy between milk production and body reserves, as well as to a dilution effect of secreted milk solids (Journet and Dulphy, 1973; Coulon et al, 1995). In this trial, contrary to that which we observed previously, it would appear that the majority of the differences observed were due to a dilution effect of secreted milk solids. Indeed, the energy balance was identical for the two types of forage and the variations in live weight were similar.

The reasons for this dilution effect are not well understood. They may be linked first to the balance in end products of ruminal digestion: diets producing a high acetic/propionic ratio in the rumen are generally beneficial to milk yield, and detrimental to weight gain and protein concentration (Vérité and Journet, 1971; Thomas, 1984b). This ratio is more or less raised with grass silage-based diets (Van Vuuren et al, 1995) and depends, in particular, on the relative content in pre-formed lactic (generally degraded into propionic acid in the rumen) and acetic acids. It is therefore not certain that this ratio was more favourable with the silage than with the hay; furthermore, like Schingoethe et al (1976) and Broderick (1985), we observed the contrary in a previous trial (Coulon and Garel, 1993). Moreover, a high acetic/propionate ratio is often associated with an increase in fat production. We should have observed a close or slightly higher fat content with the grass silagebased diet, but we did not. It is therefore likely that other mechanisms of metabolic or hormonal origin (Chamberlain and Choung, 1993) are involved, related or not to digestive end products and to their rate of appearance (modification of insulin secretion), and that these, for example, affected lactose production (and the- 
refore water excretion) without affecting fat and protein formation.

This study shows that the way in which forages are preserved can have a substantial specific effect on dairy cow performances. Further work is, however, necessary to clarify the reasons for these effects and the factors which could influence the outcome of such comparisons (forage species, type of silage fermentation, level of nutritive supplies).

\section{ACKNOWLEDGMENTS}

We thank E Albaret, $M$ Javorek and their staff for the samplings and measurements, and the 'Pôle Fromager AOC Massif-Central' with the participation of which this study was performed.

\section{REFERENCES}

Bertilsson J, Burstedt E (1983) Effects of conservation method and stage of maturity upon the feeding value of forages to dairy cows. 1. Forage intake and effects of concentrate/forage ratio. Swed $J$ Agric Res 13, 189-200

Broderick GA (1985) Alfalfa silage or hay versus corn silage as the sole forage for lactating dairy cows. J Dairy Sci 68, 3262-3271

Burstedt E, Lingvall P (1977) The effect of conservation system and stage of development of herbage on milk production. In : Proc 13th Int Grassland Congr, Leipzig, Germany, 610-616

Chamberlain DG, Choung JJ (1993) The nutritional value of grass silage. In: Proc I0th Int Conf on Silage Research, Dublin, Ireland, 131-136

Coulon JB, Garel JP (1993) A note on the effect of forage type on the yield, chemical composition and clotting properties of milk. Anim Prod 57. 495-499

Coulon JB, Garel JP, Hoden A, Journet M, Liénard $G$ (1985) Production laitière en zone de montagne : effets pluriannuels du type de ration hivernale et du niveau de complémentation. Bull Tech $C R Z V$ Theix, INRA 61, 31-48

Coulon JB, Pradel P, Verdier I (1995) Effect of forage type on milk yield, chemical composition and clotting properties of milk. Lait 75, 513-521
Demarquilly C (1963) Influence de la nature du pâturage sur la production laitière et la composition du lait. Ann Zootech 12, 69-104

Dulphy JP, Demarquilly C (1981) Problèmes particuliers aux ensilages. In: Prévision de la valeur nutritive des aliments des ruminants. INRA publications ed, Versailles, France, 81-104

Institut national de la recherche agronomique (INRA) (1989) Ruminant Nutrition. Recommended allowances and Feed Tables (R Jarrige, ed), John Libbey Eurotext, London, UK

Journet M, Dulphy JP (1973) Utilisation des ensilages d'herbe par les vaches laitières. Fourrages 56, 71-87

Rowland SJ (1938) The determination of the nitrogen distribution in milk. J Dairy Res 9, 42-46

SAS Institute Inc (1987) SAS User's Guide: Statistics. SAS Istitute Inc, Cary, NC, USA

Schingoethe DJ, Voelker HH, Beardsley GL, Parsons JG (1976) Rumen volatile fatty acids and milk composition from cows fed hay, haylage, or ureatreated corn silage. J Dairy Sci 59, 894-901

Sjaunja LO (1989) Methods for Calculation of the Energy Content of Milk. International Commission for Recording the Productivity of Milk Animal (ICRPMA), Brussels, Belgium

Thomas C (1984a) Milk compositional quality and the rôle of forages. In: Milk Compositional Quality and its Importance in Future Markets (ME Castle, RG Gunn, eds), Occ Publ Br Soc Anim Prod, UK, $9,69-76$

Thomas PC (1984b) Feeding and milk production. In: Milk Compositional Quality and its Importance in Future Markets (ME Castle, and RG Gunn, ed), Occ Publ Br Soc Anim Prod, UK, 9, 53-67

Thompson DJ, Beever DE, Haines MJ, Cammell SB, Evans RT, Dhanoa MS, Austin AR (1985) Yield and composition of milk from Friesian cows grazing either perennial ryegrass or white clover in early lactation. J Dairy Res 52, 17-31

Van Vuuren AM, Huhtanen P, Dulphy JP (1995) Improving the feeding and health value of ensiled forages. In: Recent Developments in the Nutrition of Herbivores. Proceedings of the Ivth Intemational Symposium on the Nutrition of Herbivores (M Journet, E Grenet, MH Farce, M Theriez, C Demarquilly, eds), INRA Editions, Paris, France, 279-307

Vérité R, Journet M (1971) Utilisation comparée de l'ensilage de maïs et de l'ensilage d'herbe pour la production laitière. Ann Zootech 20, 153 167 